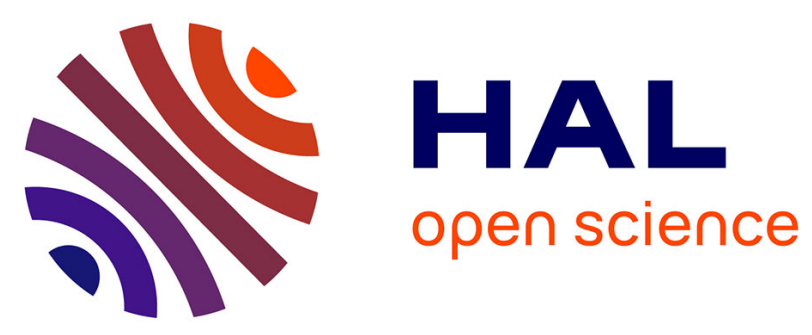

\title{
A new species of the genus Stigmaeus koch (Acari: Stigmaeidae) from Kurdistan province, Iran and description of male of Prostigmaeus khanjanii Bagheri and Ghorbani
}

\author{
Mohammad Khanjani, F. Amini, Masoumeh Khanjani
}

\section{To cite this version:}

Mohammad Khanjani, F. Amini, Masoumeh Khanjani. A new species of the genus Stigmaeus koch (Acari: Stigmaeidae) from Kurdistan province, Iran and description of male of Prostigmaeus khanjanii Bagheri and Ghorbani. Acarologia, 2015, 55 (1), pp.49-60. 10.1051/acarologia/20152153 . hal01548347

\author{
HAL Id: hal-01548347 \\ https://hal.science/hal-01548347
}

Submitted on 27 Jun 2017

HAL is a multi-disciplinary open access archive for the deposit and dissemination of scientific research documents, whether they are published or not. The documents may come from teaching and research institutions in France or abroad, or from public or private research centers.
L'archive ouverte pluridisciplinaire HAL, est destinée au dépôt et à la diffusion de documents scientifiques de niveau recherche, publiés ou non, émanant des établissements d'enseignement et de recherche français ou étrangers, des laboratoires publics ou privés.

\section{(ㅇ)(1) $\$$}

Distributed under a Creative Commons Attribution - NonCommercial - NoDerivatives 44.0 


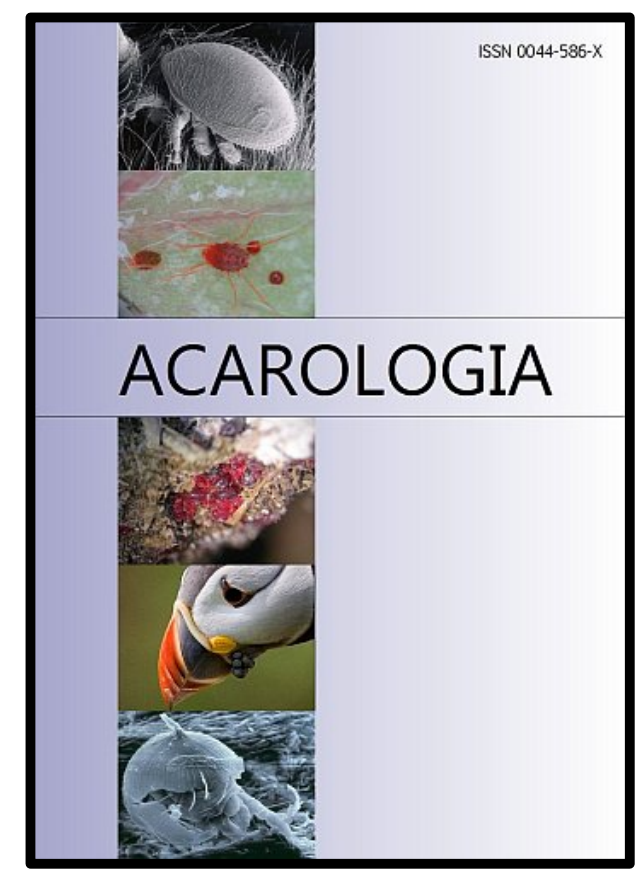

\section{ACAROLOGIA}

A quarterly journal of acarology, since 1959

Publishing on all aspects of the Acari

All information:

http://www1.montpellier.inra.fr/CBGP/acarologia/ acarologia@supagro.inra.fr

\section{OPEN ACCESS}

\section{Acarologia is proudly non-profit, with no page charges and free open access}

Please help us maintain this system by encouraging your institutes to subscribe to the print version of the journal and by sending us your high quality research on the Acari.

Subscriptions: Year 2017 (Volume 57): $380 €$ http://www1.montpellier.inra.fr/CBGP/acarologia/subscribe.php

Previous volumes (2010-2015): $250 € /$ year (4 issues)

Acarologia, CBGP, CS 30016, 34988 MONTFERRIER-sur-LEZ Cedex, France

The digitalization of Acarologia papers prior to 2000 was supported by Agropolis Fondation under the reference ID 1500-024 through the « Investissements d'avenir » programme

(Labex Agro: ANR-10-LABX-0001-01)
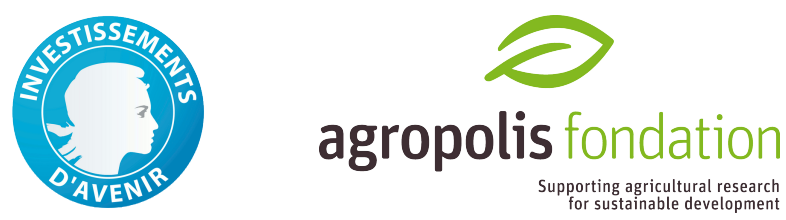

Acarologia is under free license and distributed under the terms of the

Creative Commons-BY-NC-ND which permits unrestricted non-commercial use, distribution, and reproduction in any medium, provided the original author and source are credited. 


\title{
A new species of the genus Stigmaeus koch (Acari: Stigmaeidae) from Kurdistan province, Iran and description of male of Prostigmaeus khanjanii Bagheri and Ghorbani
}

\author{
Mohammad KHANJANI, Fatemeh AMINI and Masoumeh KHANJANI \\ (Received 10 November 2014; accepted 27 November 2014; published online 30 March 2015) \\ Department of Plant Protection, College of Agriculture, Bu-Ali Sina University, Hamedan, Iran. mkhanjani@gmail.com, \\ fatemehamini362@yahoo.com,mh.khanjani86@gmail.com
}

\begin{abstract}
A new species of the genus Stigmaeus, S. kurdistaniensis n. sp. is described and illustrated based on females collected from soil under apple trees, Ghorveh city, Kurdistan province, Iran. In addition, the male of Prostigmaeus khanjanii Bagheri and Ghorbani, 2010 is described. A key to all known Iranian species of the genus Stigmaeus is provided.

KEYWORDS - Arthropods; soil; predatory mite; ectoparasites; apple tree
\end{abstract}

\section{INTRODUCTION}

Stigmaeidae is the largest family within Raphignathoidea, which was established by Oudemans (1931). Members of this family are predators and feed on arthropods, ectoparasites of dipterans and pollen feeders (Summers 1966; Ueckermann and Smith Meyer 1987; Fan and Zhang 2005).This family currently contains 32 genera, of which 12 genera are recorded from Iran (Bayzavi et al. 2013). The genus Stigmaeus Koch occurs all over the world but the genus Prostigmaeus Kuznetsov has only been recorded from palaearctic and afrotropical regions (Fan and Zhang, 2005). To date, 4 species of the genus Prostigmaeus and 33 species of Stigmaeus have been recorded and described from Iran (Khanjani et al. 2014; Bagheri et al. 2014; Bagheri et al. 2010), namely: Prostigmaeus khanjanii Bagheri and Ghorbani, 2010; P. molaviae Khanjani et al., 2012; P. tauricus Kuznetsov, 1984; P. vrystaatensis Ueckermann and Meyer, 1978 and Stigmaeus alvandis Khanjani and Ueckermann, 2002; S. boshroyehensis Khanjani et al., 2010; S. candidus Fan and Li, 1993 (=S. mazandaranicus Faraji and Ueckermann, 2006); S. cariae Khanjani et al., 2012; S. delaramae Khanjani et al., 2014; S. echinopus Summers, 1962 (Ahaniazad et al. 2013); S. elongatus Berlese, 1886; S. fissicomus Ueckermann and Mayer, 1987 (Kamali et al. 2001); S. glypticus Summers, 1962 (Hajizadeh et al. 2013); S. isfahaniensis Bagheri et al., 2014; S. haddadi Zarei and Bagheri, 2012; S. iranensis Bagheri et al., 2012a; S. kermaniensis Changizi et al., 2012; S. kermanshahiensis Khanjani et al., 2012; S. ladanae Nazari et al., 2012; S. longipilis Canestrini, 1889 (Pahlevan Yali et al. 2011); S. malekii Haddad Irani-Nejad et al., 2006; S. maraghehiensis Bagheri et al., 2012b; S. marandiensis Bagheri et al., 2011b; S. miandoabiensis Bagheri and Zarei, 2012; S. nasrinae Nazari et al., 2012; S. petrophilus Kuznetsov and Petrova, 1979 (Hajizadeh 
et al. 2013); S. pilatus Kuznetzov, 1987 (Khanjani et al. 2010); S. pulchellus Kuznetzov, 1978 (Zarei and Bagheri 2012); S. shabestariensis Haddad Irani-Nejad et al., 2010a; S. shendabadiensis Haddad Irani-Nejad et al., 2010b; S. siculus (Berlese 1883) (Bagheri and Zarei 2012); S. sphangeti (Hull 1918) (Akbari et al. 2010); S. ueckermanni Pahlavan Yali et al., 2011; S. unicus Kuznezov, 1978 (Khanjani and Ueckermann 2002); S. sinai Swift, 1987; S. makouensis Bagheri et al., 2013; S. saboorii Bagheri et al., 2013. In this paper, S. kurdistaniensis n. sp. and the male of Prostigmaeus khanjanii Bagheri and Ghorbani are described for the first time from Iran.

\section{MATERIALS AND METHODS}

Mites were collected from soil under apple and fig trees in Kurdistan and Hamedan provinces and mounted directly in Hoyer's medium. The specimens were measured, identified and drawn by means of an Olympus $\mathrm{BX}_{51}$ differential interference contrast microscope under 1000X magnification and equipped with a drawing tube. Body length measurements represent the distance between base of gnathosoma and end of idiosoma; width was measured above coxae III. Setae were measured from the setal base to the tip of the seta; distances between setae were measured between setal bases. Legs measurements are from trochanter to tip pretarsus.

The terminology and abbreviations used in the description of the new species follows that of Kethley (1990). Leg chaetotaxy is adapted from Fan and Zhang (2005). All measurements are given in micrometers and the measurements of the paratype are given in parentheses.

\section{RESULTS}

\section{FAMily STIGMAEIDAe OUdemans, 1931}

\section{Genus: Stigmaeus Koch, 1836: 4, 9.}

Type species: Stigmaeus cruentus Koch, 1836 (unknown), by original designation.

Diagnosis - (Based on Fan and Zhang, 2005).
Female - Idiosoma narrowly to broadly oval in dorsoventral view, white, yellow, red or dark red in life. Chelicerae separate. Palptibial claw subequal to or slightly shorter than palptarsus; accessory claw seta-like or spine-like; terminal eupathidia on palptarsus basally fused and split into 3 long prongs or simple; counts of setae and solenidia from palptrochanter to palptarsus: $0,3,2,2+1$ claw +1 accessory claw, $4+1 \omega+1$ sub-terminal spine-like eupathidium +3 eupathidia (basally fused). Prodorsum usually with a large shield, bearing 3 pairs of setae ( $v i$, ve and sci) and a pair of platelets bearing setae sce; eyes present or absent, post-ocular bodies (pob) present or absent.

Dorsal hysterosomal areas C-F usually with 1-2 shields surrounded by 3-5 pairs of platelets, sometimes much reduced or absent, shields with 2-3 pairs of setae; setae $d_{1}$ and $d_{2}$ never on same shield; humeral shields large or small, dorso- or ventrolateral, with setae $c_{2}$; intercalary shields (F) obvious, entire or divided along midline, with a pair of setae $\left(f_{1}\right)$. Suranal shield $(\mathrm{H})$ entire or divided, with 23 pairs of setae ( $h_{3}$ absent or present). Endopodal shields I-II and III-IV present, divided along midline. Ventral opisthosoma with 3-5 pairs of aggenital setae; genital and anal valves fused or contiguous, with 1-3 pairs of genital setae and 3 pairs of pseudanal setae.

Leg tarsal claws robust; empodial shafts branching into tenent hairs before extending beyond tips of claws, with 3 pairs of tenent hairs; counts of setae and solenidia on legs I-IV: coxae (excluding $1 a, 3 a$ and $4 a) 2+1$ elcp, 2, 2, 2; trochanters 1, 1, 2, 1; femora 4-6, 4-6, 3, 2; genua 3-5 + $1 \kappa, 3-4+0-1 \kappa, 0-3,0-3$; tibiae $5+0-1 \varphi+1 \varphi \rho, 5+1 \varphi \rho, 5+1 \varphi \rho, 5+1 \varphi \rho$; tarsi $13+1 \omega, 8-9+1 \omega, 7+1 \omega, 6-7+0-1 \omega$. Male. Solenidia on tarsi I-IV: 2, 2, 2, 2.

\section{Stigmaeus kurdistaniensis n. sp.}

(Figs. 1-2)

Diagnosis - Prodorsum with large, reticulated shield; eyes absent and post-ocular bodies present; median hysterosomal shield with 2 pairs of setae; suranal shield entire, with 2 pairs of setae $\left(h_{3}\right.$ absent). All dorsal shields reticulated. Endopodal shields and coxal areas reticulated; dorsal setae long 

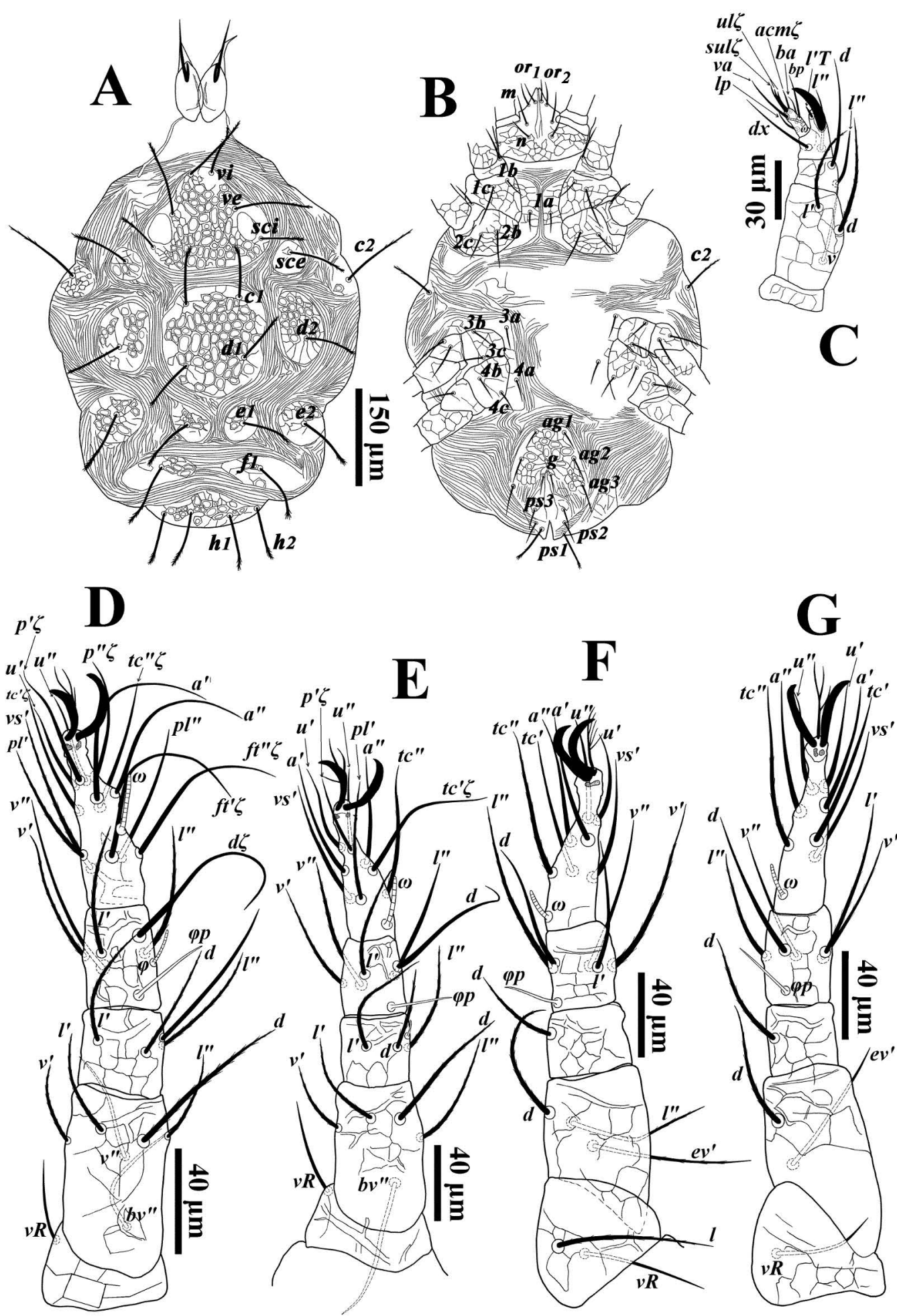

FIgURE 1: Stigmaeus kurdistaniensis n. sp. (female): A - Dorsal view; B - Ventral view; C - Palp; D - Leg I; E - Leg II; F - Leg III; G - Leg IV. 

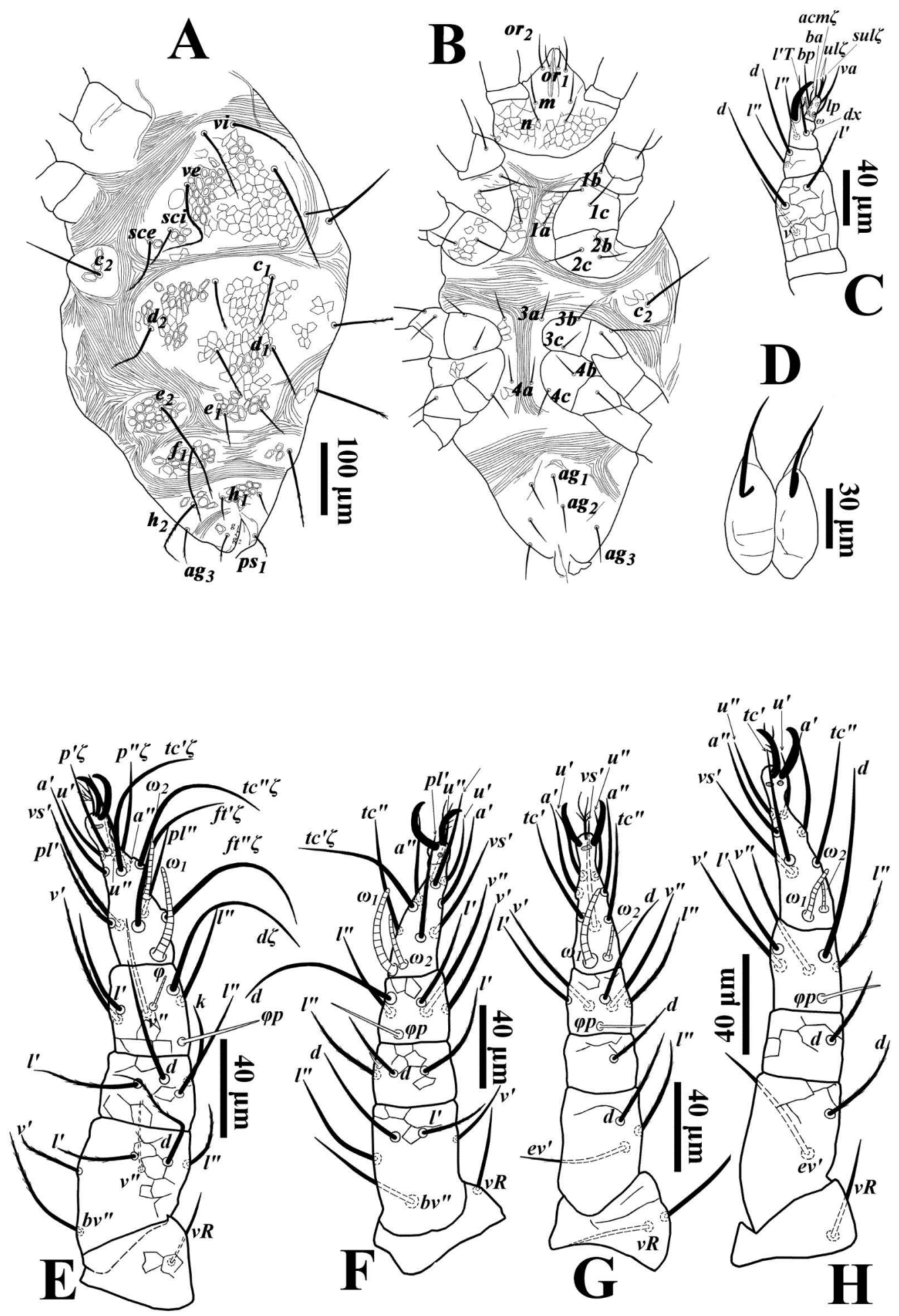

FIGURE 2: Stigmaeus kurdistaniensis n. sp. (male): A - Dorsal view; B - Ventral view; C - Palp; D - Chelicera; E - Leg I; F - Leg II; G - Leg III; H - Leg IV. 
and serrate. Aggenital plate reticulated and with 3 pairs of setae $\left(a g_{1}-a g_{3}\right)$ and genital shield with 1 pair of setae $(g)$. Palp tarsus with one tridentae eupathidium and palp genu with 2 setae. Femora I-II with 6, 5 setae respectively; genua I-IV $3(+\kappa)-3(+\kappa)$ 1-1. Palp and leg's segments with reticulations.

Type materials - Holotype female and 3 paratype females collected from soil under apple trees, Malus domestica Borkh. (Rosaceae), Iran: Kurdistan Province, Ghorveh city $\left(35^{\circ} 10^{\prime}\right.$ N, $47^{\circ} 48^{\prime}$ E, $1906 \mathrm{~m}$ a.s.l.) 4 September 2013, coll. F. Amini. The holotype female and 2 paratype females are deposited as slide-mounted specimens in the Collection of the Acarology Laboratory, University of Bu-Ali Sina, Hamadan, Iran and one paratype female will be deposited in the National Collection of Arachnida, Plant Protection Research, Pretoria, South Africa.

\section{Description}

Female $(\mathrm{n}=4)$ - Colour in life red. Idiosoma oval. Measurements of holotype with measurements of paratypes in parentheses: Length of body (excluding gnathosoma) 600 (559-618), (including gnathosoma) 761 (700 - 753); width 420 (313 - 415).

Dorsum (Figure 1A) - All dorsal shields reticulated; prodorsum with large shield medially; bearing three pairs of setae (vi, ve, sci), post ocular bodies (pob) present and eyes absent, setae sce located on small plates laterally; hysterosomal area C-E with a large shield medially and 4 pairs of small plates, median hysterosomal shield with two setae $\left(c_{1}, d_{1}\right)$, setae $d_{2}$ located on large, lateral, hysterosomal shields; ventro-lateral, humeral plate with setae $c_{2}$; intercalary shields $(\mathrm{F})$ with setae $f_{1}$; suranal shield $(\mathrm{H})$ entire, bearing 2 pairs of setae $\left(h_{1-2}\right)$. All dorsal setae long and with a cluster of barbs distally except setae $c_{2}$ sparsely serrate; setae $c_{2}$ longer than the others. Lengths of dorsal setae: vi 95 (93-97), ve $125(114-123)$, sci $73(67-75)$, sce $93(93-98), c_{1} 86$ $(82-90), c_{2} 136(130-137), d_{1} 88(82-90), d_{2} 91(86$ - 94), $e_{1} 90(82-92), e_{2} 98(87-99), f_{1} 96(87-99), h_{1}$ $90(90-92), h_{2} 85(84-86)$. Distances between dorsal setae: vi-vi 35 (39 - 40), ve-ve $100(89-103)$, sci-sci 175 (154 - 180), sce-sce $235(232-251), c_{1}-c_{1} 89$ (77 94), $c_{2}-c_{2} 420$ (312 - 417), $d_{1}-d_{1} 92(73-95), d_{2}-d_{2} 291$ (257-293), $e_{1}-e_{1} 83(73-82), e_{2}-e_{2} 292(243-289)$, $f_{1}-f_{1} 165(145-167), h_{1}-h_{1} 68(56-65), h_{2}-h_{2} 141(134$ - 142), vi-ve $125(62-125)$, ve-sci 58 (57 - 67), sci-sce 50 (37 - 47), $c_{1}-c_{2} 95$ (99 - 157), $d_{1}-d_{2} 108(92-106)$, $e_{1}-e_{2} 101(82-94), h_{1}-h_{2} 45(37-45), c_{1}-d_{1} 100(93-$ 105), $d_{1}-e_{1} 100(81-102), e_{1}-f_{1} 79(75-83), f_{1}-h_{1} 91$ (72 - 89); ratio: vi/vi-vi 2.71 (2.38), $c_{1} / c_{1}-c_{1} 0.97(0.95$ - 1.06), $d_{1} / d_{1}-d_{1} 0.96(0.99-1.17), e_{1} / e_{1}-e_{1} 1.08$ (1.12 - 1.13), $f_{1} / f_{1}-f_{1} 0.58(0.59-0.6), h_{1} / h_{1}-h_{1} 1.32(1.61-$ $1.42), c_{1}-c_{1}: d_{1}-d_{1}: e_{1}-e_{1}: f_{1}-f_{1}: 0.53(0.53-0.56): 0.55$ (0.50 - 0.56): 0.50 (0.49-0.50): $1.0(1.0)$.

Venter (Figure 1B) - Ventral cuticle striated coxisternal regions I-II and III-IV with reticulations (Figure 1B). Lengths of setae $1 a 36(35-40), 1 b 38$ (31 - 40), 1c 70 (65 - 72), $2 b 63(59-67), 2 c 42(39-43), 3 a$ 38 (38 - 42), $3 b 43(38-45), 3 c 45(31-40), 4 a 41(36$ - 43), $4 b 37(37-41), 4 c 37(33-38), a g_{1} 34(33-37)$, $a g_{2} 39(37-40), a g_{3} 49(47-50), g 27(25-30), p s_{1} 65$ $(66-73), p s_{2} 37(37-45), p s_{3} 40(39-44)$. Aggenital area reticulated, with 3 setae $\left(a g_{1-3}\right)$, setae $a g_{3}$ longer than $a g_{1-2}$; genital shield with 1 pair of setae $(g)$; anal plate with 3 pairs of setae $\left(p s_{1-3}\right)$, pseudanal setae $p s_{1}$ distally serrated and almost two times longer than setae $p s_{2-3}$.

Gnathosoma (Figure 1C) - Ventral infracapitulum with two pairs of infracapitular setae, $m 43$ (40 $-43)$ and $n 34(29-36)$, two pairs of adoral setae, or1 $29(30-32)$, or2 $38(37$ - 39) (Figure 1C). Chelicerae free 95 (95 - 100), movable digit 127 (126 - 132) (Figure 1A). Palp five segmented, palp tarsus with 4 simple setae + one simple eupathidium + one solenidion $(\omega)+$ one tridentae eupathidium, palp tibia with two setae + one well developed claw + one accessory claw seta-like, palp genu with one seta and palp femur with three setae (Figure 1C).

Legs (Figures 1D-G) - Length of leg I 253 (243 - 273); leg II 221 (208 - 238); leg III 230 (223 - 243), leg IV 251 (253 - 270). Setal formulae of leg segments (solenidia in parentheses and not included in setal counts) as follows: coxae 2-2-2-2; trochanters 1-1-2-1; femora 6-5-3-2, genua $3(+\kappa)-3(+\kappa)-1-1$; tibiae $5(+\varphi,+\varphi \rho)-5(+\varphi \rho)-5(+\varphi \rho)-5(+\varphi \rho)$; tarsi $13(+\omega)-$ $9(+\omega)-7(+\omega)-7(+\omega)$. Length of solenidia: I $\omega 25(20-$ $30)$, II $\omega 25$ (26 - 28), III $\omega 15$ (14 - 20), IV $\omega 15$ (14 18); I $\varphi \rho 39$ (37 - 39), I $\varphi 16$ (12 - 18), II $\varphi \rho 32$ (32 35), III $\varphi \rho 24(24-29)$, IV $\varphi \rho 28(27-29)$; I $\kappa 72$ (72 77), II $\kappa 12(10-11)$. 
Male ( $\mathrm{n}=1)$ - Idiosoma oval. Length of body (excluding gnathosoma) 587, (including gnathosoma) 655; width 275 .

Dorsum (Figure 2A) - Dorsal shields completely reticulated; prodorsal shield bearing four pairs of setae (vi, ve, sci, sce); post ocular bodies (pob) present; eyes absent; hysterosomal area C-F almost covered by large median and 3 pairs of plates laterally (Figure 2A); median and lateral hysterosomal shields fused, with setae $c_{1}, d_{1}, d_{2}, e_{1}$, intercalary shield divided with setae $f_{1}$; suranal shield entire, with two pairs of setae $\left(h_{1}, h_{2}\right)$. All dorsal setae barbed. Lengths of dorsal setae: vi 92, ve 107, sci 70, sce 100, $c_{1} 50, c_{2} 95, d_{1} 45, d_{2} 55, e_{1} 30, e_{2} 107, f_{1} 80$, $h_{1} 52, h_{2}$ 70. Distances between dorsal setae: vi-vi 37, ve-ve 85, sci-sci 67, sce-sce 232, $c_{1}-c_{1}$ 57, $c_{2}-c_{2} 275, d_{1}$ $d_{1} 57, d_{2}-d_{2} 182, e_{1}-e_{1} 42, e_{2}-e_{2} 150, f_{1}-f_{1} 92, h_{1}-h_{1} 37$, $h_{2}-h_{2}$ 80, vi-ve 55, ve-sci 62, sci-sce 45, c c - $c_{2} 50, d_{1}-d_{2}$ 65, e e $-e_{2} 60, h_{1}-h_{2} 25, c_{1}-d_{1} 67, d_{1}-e_{1} 60, e_{1}-f_{1} 42, f_{1}-h_{1}$ 52. Ratio: vi/vi-vi 2.48, $c_{1} / c_{1}-c_{1} 0.87, d_{1} / d_{1}-d_{1} 0.78$, $e_{1} / e_{1}-e_{1} 0.71, f_{1} / f_{1}-f_{1} 0.86, h_{1} / h_{1}-h_{1} 1.4, h_{2} / h_{2}-h_{2}$ 0.87, $h_{1} / h_{2}$ 0.74, $c_{1}-c_{1}: d_{1}-d_{1}: e_{1}-e_{1}: f_{1}-f_{1}:$ 0.62: 0.62: 0.45: 1.0 .

Venter (Figure 2B) - Endopodal shields I-II and III-IV with reticulations. Lengths of setae $1 a 22,1 b$ $35,1 c 35,2 b 35,2 c 27,3 a 2,3 b 22,3 c 17,4 a 27,4 b 25$ and $4 c 20, a g_{1} 26, a g_{2} 30, a g_{3} 38, p s_{1} 27, g_{1} 2, g_{2} 2$. Aggenital plate smooth with three setae $\left(a g_{1-3}\right)$.

Gnathosoma (Figures 2C-D) - Ventral infracapitulum reticulated and with two pairs of infracapitular setae, $m 30$ and $n 22$, two pairs of adoral setae, or1 22, or 32 (Figure 2B). Chelicerae free 132, movable digit 65 (Figure 2D). Palp five segmented, palp tarsus with 4 simple setae + one simple eupathidium + one solenidion $(\omega)+$ one tridentate eupathidium, palp tibia with two setae + one well developed claw + one spine-like accessory claw, palp genu with two seta and palp femur with three setae (Figure 2C).

Legs (Figures 2E-H) — Length of leg I 224, leg II 195; leg III 185, leg IV 205. Setation same as female except tarsi I-IV with two solenidia and solenidia longer. Length of solenidia: I $\omega_{1} 43$, I $\omega_{2} 25$, II $\omega_{1} 38$, II $\omega_{2} 22$, III $\omega_{1} 32$, III $\omega_{2} 12$, IV $\omega_{1} 26$, IV $\omega_{2} 12 ;$ I $\varphi \rho$ 35, I $\varphi$ 15, II $\varphi \rho 31$, III $\varphi \rho 20$, IV $\varphi \rho 23$; I $\kappa 55$; II $\kappa 8$.
Remarks - The new species Stigmaeus kurdistaniensis n. sp. resembles S. siculus (Berlese, 1883) in that dorsal shields are reticulated, median hysterosomal shield with two setae, pob present, eyes and $h 3$ absent. However it differs from the latter in: all dorsal and ventral setae longer than that of $S$. siculus; ventral infracapitulum and all leg and palp segments with reticulations in E. kurdistaniensis instead of smooth in S. siculus and pob small, between setae ve-sci in the new species instead of large in $S$. siculus.

The new species also resembles $S$. echinopus Summers, 1962, in having all leg and palp segments with reticulations, suranal shield entire and reticulated, pob present and median hysterosomal shield with two setae. However, S. kurdistaniensis differs from the latter in: aggenital shield reticulated instead of smooth in S. echinopus, all dorsal and ventral setae longer than those of S. echinopus and genual setae $\kappa$ short in S. kurdistaniensis in contrast to long in S. echinopus.

Immature stages - Unknown.

Etymology - The species is named after the locality where it was collected, namely Kurdistan province.

\section{Genus: Prostigmaeus Kuznetsov, 1984}

Type species: Prostigmaeus tauricus Kuznetsov, 1984

Diagnosis - (Based on Ueckermann and Meyer, 1987 and Fan and Zhang, 2005).

Female - Idiosoma elongate and somewhat spindle-shaped; prodorsum with a large shield medially, bearing 3 pairs of setae namely $v i$, ve and $s c i$; setae sce lateral to sci on integument; pob and eyes absent; humeral shields ventro-laterally, with setae $c_{2}$; opisthosoma with a relatively long median shield carrying setae $c_{1}$ and $d_{1}$; setae $e_{1}$ placed on 2 small shields posterior to median shield; intercalary shields (F) divided along midline, with a pair of setae $\left(f_{1}\right)$; suranal shield $(\mathrm{H})$ entire or divided, bearing 3 pairs of setae $\left(h_{1-3}\right)$. Chelicerae separate. Palptibial claw subequal to or slightly shorter than palptarsus; accessory claw seta-like or spinelike; terminal eupathidia on palptarsus separate, counts of setae and solenidia from palptrochanter to palptarsus: 0 , 
$3,2,2+1$ claw +1 accessary claw, $4+1 \omega+2$ subterminal spine-like eupathidia +2 unfused eupathidia; endopodal shields I-II and III-IV present; anogenital area with 4 pairs of aggenital setae $\left(a g_{1-4}\right), 3$ pairs of genital setae $\left(g_{1-3}\right)$ and 3 pairs of pseudanal setae $\left(p s_{1-3}\right)$.

Male - Solenidia on tarsi I-IV: 2, 2, 2, 2.

Prostigmaeus khanjanii Bagheri and Ghorbani, 2010 (Fig. 3)

Diagnosis - Prodorsum with large, reticulated shield medially with 3 setae (vi, ve, sci); opisthosomal shield reticulated, with 2 pairs of setae $\left(c_{1}, d_{1}\right)$, suranal shield entire, bearing 3 pairs of setae $\left(h_{1-3}\right)$. Endopodal shields I-II and III-IV present; aggenital shield with 4 pairs of setae $\left(a g_{1-4}\right)$; genital plate with 3 pairs of setae $\left(g_{1-3}\right)$. Palp genu with 2 setae; terminal eupathidia on palptarsus separate.

Leg segments' setal formulae as follows: coxae 2-2-2-2; trochanters 1-1-2-1; femora 6-4-3-2, genua $5(+\kappa)-5(+\kappa)-2-2$; tibiae $5(+\varphi,+\varphi \rho)-5(+\varphi \rho)-5(+\varphi \rho)-$ $5(+\varphi \rho)$; tarsi $13(+\omega)-9(+\omega)-7(+\omega)-7(+\omega)$.

Male. As in female but: shields of hysterosomal area E-F fused; Tarsi I-IV with two solenidia.

\section{Description}

Male $(\mathrm{n}=3)$ - Idiosoma elongate. Length of body (excluding gnathosoma) 377 - 417, (including gnathosoma) 433-470; width 197.

Material examined - Three males collected from soil under fig trees, Ficus carica L. (Moraceae), Iran: Hamedan Province, Heydareh village ( $34^{\circ} 48^{\prime} 27^{\prime \prime} \mathrm{N}, 48^{\circ} 28^{\prime} 0.85^{\prime \prime}$ E, 1873 m a.s.1.), 6 November 2013, coll. F. Amini. Deposited as slidemounted specimens in the Collection of the Acarology Laboratory, University of Bu-Ali Sina, Hamadan, Iran.

Dorsum (Figure 3A) - Prodorsum with rather large reticulations, large shield bearing 3 pairs of setae (vi, ve, sci); post ocular bodies (pob) and eyes absent; hysterosoma with an elongate, large median shield, with 2 setae $\left(c_{1}, d_{1}\right)$; zonal and intercalary shields fused, bearing 2 pairs of setae $\left(e_{1}, f_{1}\right)$; suranal shield entire and with 2 pairs of setae $\left(h_{1}, h_{2}\right)$. All hysterosomal shields reticulated. Lengths of dorsal setae: vi $19-23$, ve $19-24$, sci $24-25$, sce $21-22$, $c_{1} 11-13, c_{2} 23-27, d_{1} 8-11, d_{2} 14-17, e_{1} 11-16$, $e_{2} 10-15, f_{1} 9-11, h_{1} 21-26, h_{2} 21-24, h_{3} 20-23$. Distances between dorsal setae: vi-vi $23-26$, ve-ve $43-46$, sci-sci $54-57$, sce-sce $120-127, c_{1}-c_{1} 35-41$, $c_{2}-c_{2} 212-220, d_{1}-d_{1} 28-30, d_{2}-d_{2} 320-325, e_{1}-e_{1} 92$ $-95, e_{2}-e_{2} 118-123, f_{1}-f_{1} 57-63, h_{1}-h_{1} 42-43, h_{2}-h_{2}$ $59-63, h_{3}-h_{3} 27-37$, vi-ve $41-45$, ve-sci $46-49$, scisce $35-43, c_{1}-c_{2} 84-91, d_{1}-d_{2} 63-71, e_{1}-e_{2} 46-53$, $h_{1}-h_{2} 11-14, c_{1}-d_{1} 61-63, d_{1}-e_{1} 62-66, e_{1}-f_{1} 30-32$, $f_{1}-h_{1} 48-49$. Ratio: vi/vi-vi $0.83-0.88, c_{1} / c_{1}-c_{1} 0.30-$ $0.31, d_{1} / d_{1}-d_{1} 0.28-0.36, e_{1} / e_{1}-e_{1} 0.10-0.16, f_{1} / f_{1}-f_{1}$ $0.15-0.17, h_{1} / h_{1}-h_{1} 0.05-0.06, h_{2} / h_{2}-h_{2} 0.35-0.45$, $h_{1} / h_{2} 0.35-0.38, c_{1}-c_{1}: d_{1}-d_{1}: e_{1}-e_{1}: f_{1}-f_{1}: 0.61-0.65:$ 0.47 - 0.49: 1.50 - 1.61: 1.0 .

Venter (Figures 3B-C) - Ventral cuticle with striae; endopodal shields II-III and III-IV present and smooth (Figure 17). Lengths of setae $1 a 17$ $21,1 b 22-25,1 c 24-30,2 b 32-37,2 c 31-32,3 a$ $26-31,3 b 20-24,3 c 15-18,4 a 21-26,4 b 14-17$ and $4 c 17-18, a g_{1} 18-24, a g_{2} 19-21, g_{1} 2-3, g_{2} 3$ $-5, p s_{1} 15-17$. Aggenital plate with striae and two setae $\left(a g_{1-2}\right)$. Genital plate indicated in figure 18 .

Gnathosoma (Figure 3D) - Ventral infracapitulum with two pairs of subcapitular setae, $m 15-18$ and $n 16-17$, two pairs of adoral setae, or $17-10$, or $5-6$ (Figure 3B). Chelicerae free $58-63$, movable digit $29-34$ (Figure 3A). Palp five segmented, palp tarsus with 4 simple setae + one solenidion $(\omega)$ +2 subterminal spine-like eupathidia +2 separate eupathidia, palp tibia with two setae + one well developed claw + one spine-like accessory claw, palp genu with two seta and palp femur with three setae (Figure 3D).

Legs (Figures 3E-H) - Length of leg I 163 167; leg II 123 - 125; leg III 124 - 128, leg IV 150 - 155. Setal formulae of leg segments (solenidia in parentheses and not included in setal counts) as follows: coxae 2-2-2-2; trochanters 1-1-2-1; femora 6-4-3-2, genua $5(+\kappa)-5(+\kappa)-2-2$; tibiae $5(+\varphi,+\varphi \rho)-$ $5(+\varphi \rho)-5(+\varphi \rho)-5(+\varphi \rho)$; tarsi $13\left(+\omega_{1},+\omega_{2}\right)-9\left(+\omega_{1},+\right.$ $\left.\omega_{2}\right)-7\left(+\omega_{1},+\omega_{2}\right)-7\left(+\omega_{1},+\omega_{2}\right)$. Length of solenidia: I $\omega_{1} 29-35$, I $\omega_{2} 17-19$, II $\omega_{1} 28-29$, II $\omega_{2} 13-14$, III $\omega_{1} 25-29$, III $\omega_{2} 4-6$, IV $\omega_{1} 23-26$, IV $\omega_{2} 6-7$; I $\varphi \rho$ $19-24$, I $\varphi 6-9$, II $\varphi \rho 15-18$, III $\varphi \rho 11-15$, IV $\varphi \rho$ $14-16$; I $\kappa 3-5$; II $\kappa 4-7$.

Remarks - Males of this species exhibit all fea- 

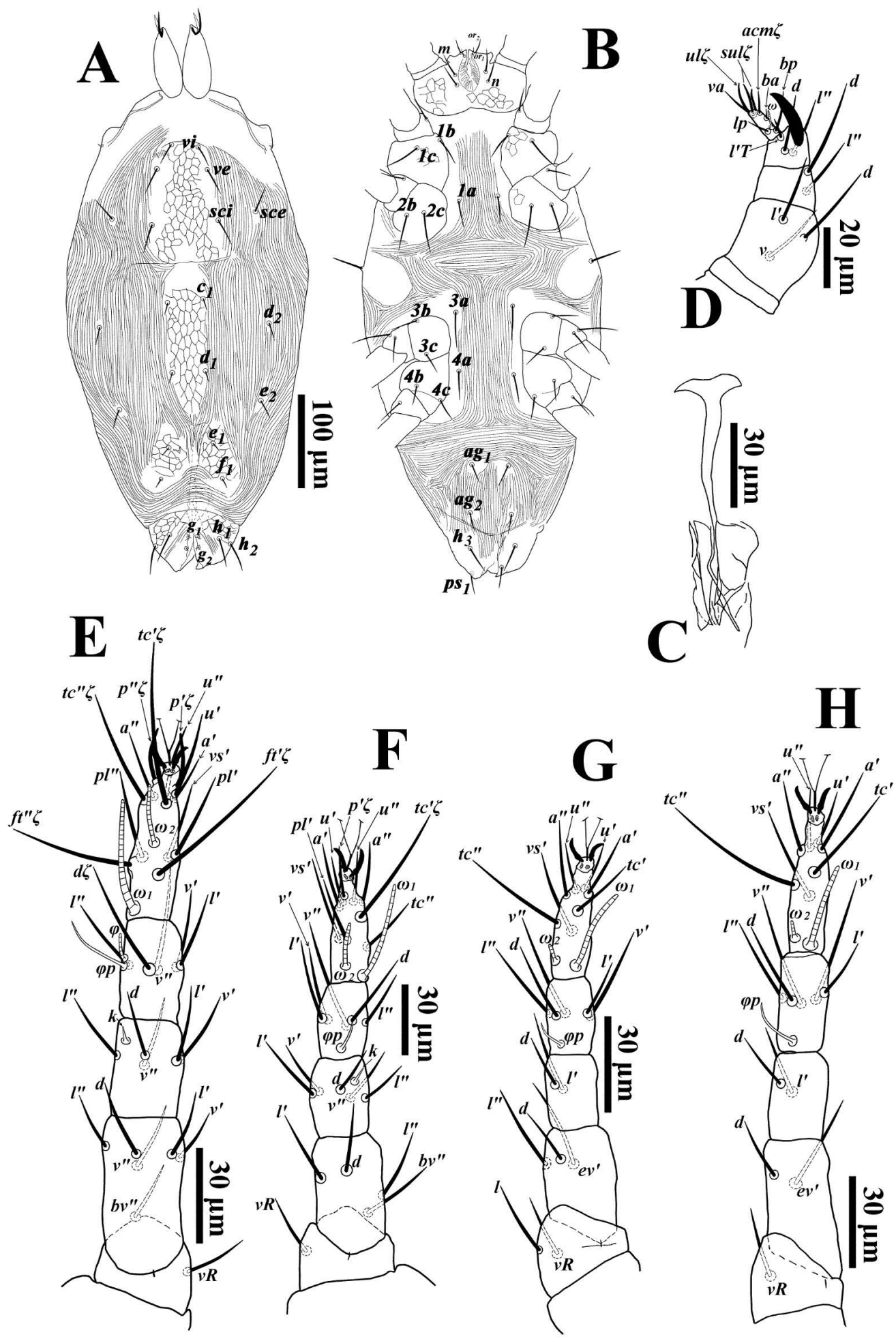

FIgURE 3: Prostigmaeus khanajnii Bagheri and Ghorbani (male): A - Dorsal view; B - Ventral view; C - Genital plate; D - Palp; E - Leg I; F - Leg II; G - Leg III; H - Leg IV. 
tures of the female descriptions, except that the male tarsi I-IV are with two solenidia instead of one solenidion in female, zonal and intercalary shields fused, bearing 2 pairs of setae $\left(e_{1}, f_{1}\right)$ whereas completely separate in the female.

\section{Key to the Iranian species of genus Stigmaeus (Female)}

1. Median propodosomal shield absent. . . .2

- Median propodosomal shield present 3

2. Genua II-III with 5-3 setae S. saboorii - Genua II-III with 4-4 setae. . S. kermaniensis

3. Hysterosoma without median shield .........4

— Hysterosoma with median shield ............. 7

4. Genua II-IV with 2-0-1 setae 5

- Genua III-IV with 5-3-3 seate ... S. elongatus

5. Femora I-II with 4-4 setae, suranal shield divided................................6 6 - Femora I-II with 6-5 setae, suranal shield entire. .... S. candidus

6. Prodorsal shield smooth, aggenital setae $a g_{1-2}$ inserted on soft cuticle, genu I with one solenidiun......................... S. shendabadiensis - Prodorsal shield in center region reticulated, aggenital setae $a g_{1-2}$ inserted on entire shield, genu I without solenidiun . . . S. nasrinae

7. Median hysterosomal shield with 2 pairs of setae.................................. 8 - Median hysterosomal shield with 3 pairs of setae................................... 25

8. Femur I with 4 setae $\ldots \ldots \ldots \ldots \ldots \ldots$

— Femur I with 6 setae....................21

9. Femur IV with 1 seta............... S. alvandis

— Femur IV with 2 setae ................... 10
10. Genu I with 3 (1) setae S. ueckermannii

- Genu I with 5 (1) setae ... 11

11. Genu III without seta ...................12

— Genu III with 1 or 2 setae. 15

12. Genu IV with 1 seta $\ldots \ldots \ldots \ldots \ldots \ldots \ldots 13$

- Genu IV with 2 setae 14

13. Genu II with 2 setae................. S. cariae — Genu II with 3 setae. S. miandoabiensis

14. Genu II with 3 setae; seta $h_{3}$ present; prodorsal shield reticulated ............. S. kermanshahiensis - Genu II with 4 setae; seta $h_{3}$ absent; prodorsal shield smooth ..................... S. iranensis

15. Genua II-III with $4-1$ setae ............... 16

— Genua II-III with 5-2 setae................18

16. Prodorsal, median, lateral and median zonal shields reticulated ............... S. makouiensis - Prodorsal, median, lateral and median zonal shields smooth...........................17

17. Palp tarsus with one bifurcate eupathidium......................... isfahaniensis - Palp tarsus with one tridentate eupathidium......................... S. marandiensis

18. Suranal shield entire....................19 — Suranal shield divided.............. S. pulchellus

19. Dorsal shields heavily ornamented with polygonal cells; tarsi II with 9 (1) setae ............. 20 - Dorsal shields reticulated, tarsi II with 8 (1) setae......................... S. maraghehiensis

20. Coxisternal, ano-genital shields, hypostome and legs reticulated ..................... S. ladanae - Coxisternal, ano-genital shields and legs smooth and hypostome punctuated .......S. shabestariensis 
21. Femur II with 4 setae ................. 22

— Femur II with 5 setae.................... 24

22. Genua III-IV without setae ........... S. unicus

— Genua III-IV with 1 setae ..............23

23. Prodorsal shield smooth, eyes present, 3 pairs aggenital setae ................... pilatus - Prodorsal shield polygonal reticulated, eyes absent, 5 pairs aggenital setae. S. sinai

24. Genital region with 3 pairs of aggenital $\left(a g_{1-3}\right)$ and 1 pair of genital setae $\left(g_{1}\right)$, tarsi I-II with $13(1)$ 9(1) setae ............................ 25

- Genital region with 4 pairs of aggenital $\left(a g_{1-4}\right)$ and 2 pairs of genital setae $\left(g_{1-2}\right)$, tarsi I-II with $13(1)$ $9(1)$ setae .................... . petrophilus

25. Genu II with $3(+\kappa)$ setae, aggenital region with polygonal reticulations..................26 - Genu II with 4 setae, aggenital region smooth..................... echinipus

26. Leg segments with reticulation, dorsal setae long, setae vi 93-95, ve 125$122 \ldots \ldots \ldots \ldots \ldots \ldots \ldots$. S. kurdistaniensis n. sp. - Leg segments smooth, dorsal setae shorter, setae vi 40-45, ve $75-86 \ldots \ldots \ldots \ldots \ldots . . \ldots$. . . siculus

27. Femur II with 4 setae ................. 28

— Femur II with 5 setae. ................... 29

28. Eyes present; tarsi II with 9 (1) setae....................... boshroyensis — Eyes absent; tarsi II with 7 (1) setae.....S. maleki

29. Genua III with 1 smooth seta, prodorsal shield reticulated ........................ 30 - Genua III with 1 barbed, prodorsal shield smooth. S. longipilis

30. Tarsi I with $13(1)$ setae ................ 31

— Tarsi I with 12 (1) setae ............ S. glypticus
31. Aggential region with 3 pairs of setae $\left(a g_{1-3}\right) .32$ - Aggential region with 2 pairs of setae $\left(a g_{1-2}\right) \ldots \ldots \ldots \ldots \ldots \ldots \ldots . \ldots . . \ldots \ldots$. fissicomus

32. Coxisternal and legs reticulated .......... 33

- Coxisternal and legs smooth .......... S. haddadi

33. Ratio setae $d / v^{\prime \prime}$ on tibia IV 0.9 ; setae $d$ on tibia

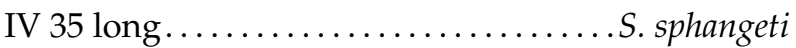
- Ratio setae $d / v^{\prime \prime}$ on tibia IV 1.4 ; setae $d$ on tibia IV 60 long ....................... delaramae

\section{ACKNOWLEDGEMENTS}

This article is a part of MSc thesis program in Agricultural Entomology of the University of Bu-Ali Sina, Iran. The authors thank the vice presidency for research of Bu-Ali Sina University for providing some material and transport for collecting mites for this project.

\section{REFERENCES}

Ahaniazad M., Bagheri M., Gholamhosein G., Maleki N. 2013 - A new species of Neophyllobius from Iran, redescription of Stigmaeus echinopus Summers and a key to the Iranian species of Neophyllobius (Acari: Trombidiformes: Prostigmata) - Internat. J. Acarol., 39(4): 341-346.

doi:10.1080/01647954.2013.777781

Akbari A., Haddad Irani-Nejad K., Bagheri M. 2010 Stigmaeid soil mites of Shendabad area (East Azarbaijan province) with one new record for Iran's fauna - In: Proceeding of 19th Iranian Plant Protection Congress; 2010 Aug 24-27; Faculty of Agriculture, University of Bu-Ali Sina, Hamedan, Iran. 344 p.

Bagheri M., Zarei E. 2012 - Stigmaeus miandoabiensis sp. nov. (Acari: Trombidiformes: Stigmaeidae), with redescription of S. siculus (Berlese, 1883) from Iran Syst. Appl. Acarol., 17(4): 441-447.

Bagheri M., Ghorbani H., Navaei Bonab R., Saber M., Mehrvar A., Ueckermann E.A. 2011a - Prostigmaeus khanjanii (Acari: Stigmaeidae), a new species from Northwest Iran — Syst. Appl. Acarol., 15: 123-128.

Bagheri M., Navaei Bonab R., Ueckermann E.A., Ghorbani H., Mehrvar A., Saber M. 2011b - Description of a new species of the genus Stigmaeus Koch (Acari: Prostigmata: Stigmaeidae) from East Azerbaijan Province, Iran — Syst. Appl. Acarol., 16: 181-186. 
Bagheri M., Gheblealivand S.S., Ghorbani H. 2012a Stigmaeus iranensis, a new species of the genus Stigmaeus Koch (Acari: Stigmaeidae) from Northwest Iran - Acarina, 20: 44-47.

Bagheri M., Ghorbani H., Ueckermann E.A., Navaei Bonab R., Saber M., Mehravar A. 2012b - Stigmaeus maraghehiensis, a new species of the genus Stigmaeus Koch (Acari: Stigmaeidae) from northwest Iran - Internat. J. Acarol., 38(1): 35-39.

Bagheri M., Maleki N., Paktinat-Saeej S. 2013 - Two new species of the genus Stigmaeus (Acari: Trombidiformes: Stigmaeidae) from Iran - Internat. J. Acarol., 39 (7): 551-557.

Bagheri M., Jafari S., Saboori A. 2014 - Two new species of the family Stigmaeidae (Acari: Trombidiformes) from Iran - Internat. J. Acarol., 40 (2): 152-159.

Bayzavi G., Ueckermann E., Faraji F., Ostovan H. 2013 A catalog of Iranian prostigmatic mites of superfamilies Raphignathoidea, Tetranychoidea (Acari) - Persian Journal of Acarology, 2(3): 389-474.

Berlese A. 1883 - Acarofauna sicula - Bollettino della Societa Entomologica Italiana, 15: 212-220.

Berlese A. 1886 - Acari dannosi alle piante coltivate Padova, $31 \mathrm{p}$.

Berlese A. 1910 - Acari nuovi - Manipulus V, VI. Redia, 6: 199-234.

Canestrini G. 1889 - Prospetto dell'Acarofauna Italiana, Famiglia degli Tetranychini - Atti del reale Istituto Veneto di Scienze, Lettere ed Arti, 7(5): 491-537.

Changizi M., Bagheri M., Asadi M. 2012 - Stigmaeus kermaniensis, a new species of the genus Stigmaeus Koch (Acari: Stigmaeidae) from Iran - Persian Journal of Acarology, 1(2): 77-84.

Fan Q.H., Li L. 1993 - Descriptions of three new species of superfamily Rhaphignathoidea (Acari: Actinedida) - Journal of Fujian Agricultural University, (Natural Sciences Edition), 22(3): 321-324.

Fan Q.H., Zhang Z.Q. 2005 - Raphignathoidea (Acari: Prostigmata). Fauna of New Zealand 52 - Lincoln (New Zealand): Mannaki Whenua Press, 400 p.

Faraji F., Ueckermann E.A. 2006 - A new species of Stigmaeus Koch from Iran (Acari: Stigmaeidae) - Syst. Appl. Acarol., 11: 69-72.

Haddad Irani-Nejad K., Bagheri M., Khanjani M., Kamali K., Saboori A. 2006 - A new species of Stigmaeus Koch (Acari: Stigmaeidae) from Northwest of Iran Zootaxa, 1354: 57-61.

Haddad Irani-Nejad P., Lotfollahi K., Akbari A., Bagheri M., Ueckermann E.A. 2010a - Stigmaeus shabestariensis (Acari: Prostigmata: Stigmaeidae) from Northwest of Iran - Syst. Appl. Acarol., 15: 118-122.
Haddad Irani-Nejad P., Lotfollahi K., Akbari A., Bagheri M., Ueckermann E.A. 2010b - A new species of Stigmaeidae mites from east Azarbaijan, Iran (Acari: Prostigmata: Stigmaeidae) - Munis Entomology, Zoology, 5(2): 369-373.

Hajizadeh J., Khanjani M., Faraji F., Ueckermann E. A. 2013 - Stigmaeid mites of Guilan Province of Iran with description of a new species and a checklist for Iranian stigmaeid mites (Prostigmata: Stigmaeidae) Internat. J. Acarol., 39 (7): 571-579. doi:10.1080/01647954.2013.850533

Hull J.E. 1918 - Terestrial Acari of the Tyne province - Transactions of the Natural History Society of Northumberland, 5: 13-88.

Kamali K., Ostovan H., Atamehr A. 2001 - A catalog of mites and ticks (Acari) of Iran - Islamic Azad University Scientific Publication Center, Tehran, Iran pp 206.

Kethley J. 1990 - Acarina: Prostigmata (Actinedida) In: Dindal, D. L. (Ed.) Soil biology Guide. John Wiley, Sons, New York, 667-756.

Khanjani M., Ueckermann E.A. 2002 - The Stigmaeid mites of Iran (Acari: Stigmaeidae) - Internat. J. Acarol., 28(4): 317-339. doi:10.1080/01647950208684309

Khanjani M., Asali-Fayaz B., Doğan S. 2012 - A new species of the genus Prostigmaeus Kuznetzov (Acari: Stigmaeidae) from western Iran - North-Western Journal of Zoology, 8(1): 27-30.

Khanjani M., Izadi H., Asali Fayaz B., Raisi H., Rostami E., Doğan S. 2010 - Stigmaeus boshroyehensis. n. sp. (Acari: Stigmaeidae) from eastern Iran, with redescription of Stigmaeus pilatus Kuznezov — Zootaxa, 2727: 34-44.

Khanjani M., Pishehvar S., Mirmoayedi A., Khanjani M. 2012 - Two new eyeless mite species of the genus Stigmaeus Koch (Acari: Stigmaeidae) from western provinces of Iran and description of the male Stigmaeus pilatus Kuznetzov — Internat. J. Acarol., 38: 504513.

doi:10.1080/01647954.2012.703690

Khanjani M., Nasrollahi S., Zamani A.S., Asali Fayaz B. 2014 - Cheylostigmaeus tarae sp. nov. and Stigmaeus delaramae sp. nov. (Acari: Stigmaeidae) from Kurdistan, Iran - Zootaxa, 3841(3): 364-378.

Koch C.L. 1836 - Deutschlands Crustaceen, Myriapoden und Arachniden - Regensburg, 4(9): pp. 1-40.

Kuznetzov N.N. 1978 - Revision of the genus Stigmaeus (Acariformes: Stigmaeidae) - Zoologicheskii Zhurnal, 57 (5): 682-694 [In Russian].

Kuznetsov N.N., Petrova A.D. 1979 - Three new species of prostigmatic mites (Acariformes, Tydeidae, Stigmaeidae), from the caves of the Caucasus and central 
Asia - Nauchnye Doklady Vysshei Shkoly Biologicheskie Nauki, 10: 30-33.

Kuznetsov N.N. 1984 - Two genera of the family Stigmaeidae - Zoologicheskii Zhurnal, 63(7): 1105-1107 [In Russian].

Nazari A., Khanjani M., Kamali K. 2012 — Two new eyeless mite species from the western provinces of Iran: Stigmaeus ladanae n. sp. and Stigmaeus nasrinae n. sp. (Acari: Stigmaeidae) - Acarologia, 52: 173-181. doi:10.1051/acarologia/20122047

Oudemans A.C. 1931 - Acarologische aanteekeningen CVIII - Entomologische Berichten, Amsterdam, 8(179): 251-263.

Pahlavan Yali M., Khanjani M., Razmjou J. 2011 — A new Stigmaeid mite species from Iran (Acari: Stigmaeidae) and re-description of Stigmaeus longipilis (Canestrini) - Zootaxa, 3089: 60-68.

Summers F.M. 1962 - The genus Stigmaeus (Acari: Stigmaeidae) - Hilgardia, 33(1): 491-537. doi:10.3733/hilg.v33n10p491

Summers F.M. 1966 - Genera of Stigmaeidae Oudemans (Acarina) - Acarologia, 8(2): 230-250.
Swift S.F. 1987 - A new species of Stigmaeus (Acari: Prostigmata: Stigmaeidae) parasitic on phlebotomine flies (Diptera: Psychodidae) - Internat. J. Acarol., 13(4): 239-243.

doi:10.1080/01647958708683778

Ueckermann E.A., Meyer M.K.P.S. 1987 - Afrotropical Stigmaeidae (Acari: Prostigmata) - Phytophylactica, 19: 371-397.

Zarei E., Bagheri M. 2012 - A new Species and new record of Stigmaeus Koch (Acari: Stigmaeidae) from northwest Iran — Syst. Appl. Acarol., 17(2): 210-216.

\section{COPYRIGHT}

(cc) EY-No-ND Khanjani M. et al. Acarologia is under free license. This open-access article is distributed under the terms of the Creative Commons-BY-NC-ND which permits unrestricted non-commercial use, distribution, and reproduction in any medium, provided the original author and source are credited. 